\title{
l'Ordre des ingénieurs forestiers du Québec
}

e prix de l'Ordre des ingénieurs fores- tiers du Québec (OIFQ) est remis annuellement à un étudiant finissant qui s'est distingué tout au long de son passage à la Faculté de foresterie, de géographie et de géomatique de l'Université Laval. Le récipiendaire doit sêtre distingué autant par ses résultats académiques que par son engagement à la vie sociale et associative de la Faculté. L'OIFQ cherche ainsi à privilégier les candidats présentant un bon équilibre entre ces deux critères, de façon à souligner l'importance du dynamisme et de l'engagement personnel tout autant que de lacquisition de connaissances et du succès scolaire.

LOrdre des ingénieurs forestiers du Québec a remis le Prix de l'Ordre 2014 à Mme Marie-Hélène Galibois. MarieHélène a terminé ses études en Aménagement et environnement forestier. Elle sest illustrée lors de son passage à la Faculté par l'excellence de son dossier académique et par son implication au sein de la vie étudiante, notamment à l'Association étudiante, sur le Comité de programme en aménagement et environnement forestier, à la Semaine des sciences forestières, au Café étudiant de la Faculté et à la COOP de solidarité des

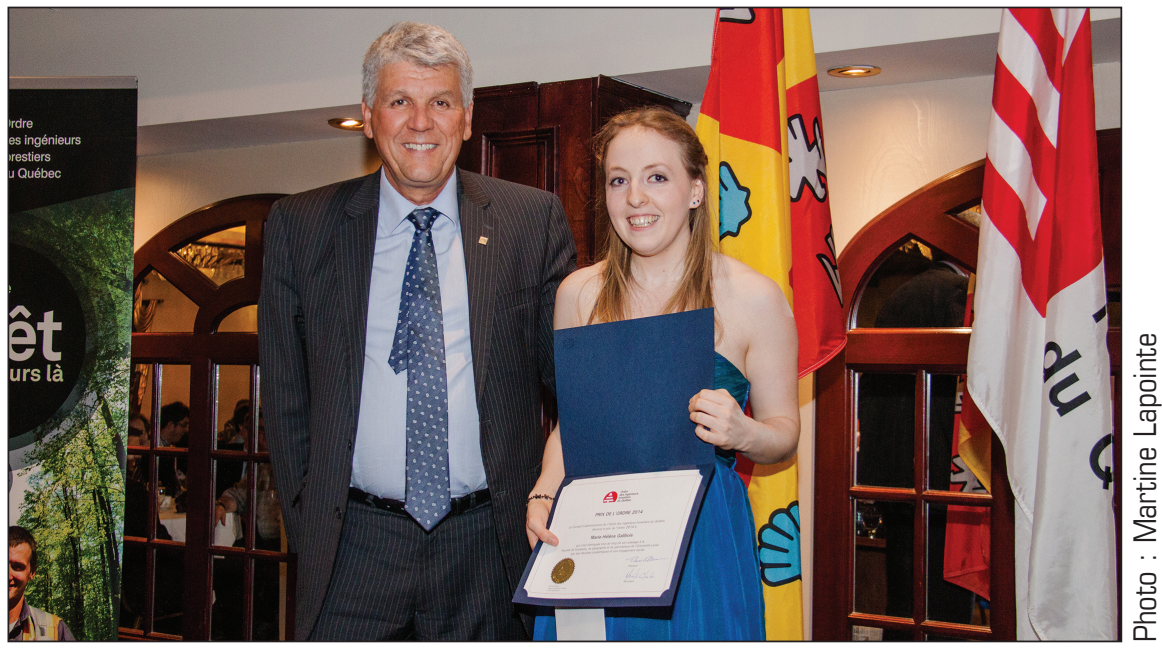

Mme Marie-Hélène Galibois a reçu le Prix de l'Ordre 2014 des mains de M. Denis Villeneuve, ing.f., président de l'OIFQ, à l'occasion de la cérémonie de remise des joncs de l'Université Laval, le 25 avril 2014, à Québec.

cafés étudiants de l'Université Laval. Adepte d'aventures et de plein-air, Marie-Hélène s'est également impliquée dans la mission détude à Madagascar, une mission qui a permis à une dizaine de ses consœurs et confrères de classe de visiter l'Île de Madagascar, en mai dernier.

Marie-Hélène est une personne enthousiaste et engagée. C'est une fon- ceuse et une leader. Toutes ces qualités la préparent à une belle carrière d'ingénieur forestier et font d'elle une récipiendaire de marque du Prix de l'Ordre des ingénieurs forestiers du Québec. Tous les ingénieurs forestiers du Québec félicitent Marie-Hélène pour son parcours exceptionnel et lui souhaitent la meilleure des chances dans sa carrière!

\section{BOOK ANNOUNGEMENTS : PUBLICATIONS RÉCENTES}

\section{Journeys Through Eastern Old-Growth Forests - A Narrative Guide}

Jamie Simpson. 2014. ISBN 978-1-77108-131-3 Nimbus Publishing Ltd. Halifax, Nova Scotia.\$21.95 + shipping. Contact: emackinnon@nimbus.ca

Y es, there is old-growth forest in the Maritimes. The Acadian Forest, as it is known, is a complex mosaic of various species and ages. Now left only in pockets scattered here and there, these forests will stop you in your tracks, invite you to gaze upwards, and fill you with wonder.

This book begins with a collection of stories about journeys into these old forests, and ends with detailed profiles of 16 of the remaining pockets of oldgrowth forest in the Maritimes: nine in Nova Scotia, three in New Brunswick, and four in Prince Edward Island. Each site description includes notes on what a visitor can expect to see, and a map and directions showing how to get there. Over 75 colour photographs highlight the incredible beauty and diversity of the region's forests.

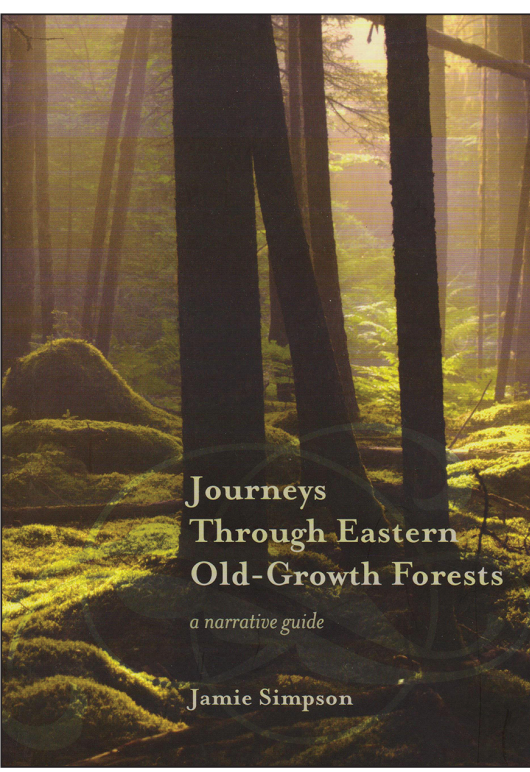

